Технологія спільного спалення відходів у цементних печах зарекомендувала себе надійним, ефективним та зручним методом утилізачіі відходів (побутових та промислових). Проте краӥни по всвому світу зіштовхуються з наступними ключовими бар'єрами на шляху до впровадження технології сумісної переробки відходів у цементних печах: нечітке законодавство, відсутність фінансової підтримки, сприйняття громадсъкістю, тощо. Ці бар'єри можуть бути частково усунуті за допомогою заходів, запропонованих у цьому дослідженні.

Крім того, сортування та переробка відходів часто не проводяться систематично. Національні та міжнародні цементні компанії працюють із сучасними печами, які можуть замінити частину викопного палива та сировини відповідними потоками підготовлених відходів, які підлягають спільному спаленню. Спільне спалення відходів, що не підлягають вторинній переробці, є надійним варіантом закриття існуючих прогалин для впровадження принципів циркуляційної економіки. Ця технологія иироко використовується в різних крайнах Свропи, але з різним екологічним впливом на навколишнє середовище. Отже, важливим є дослідити екологічний потенціал иієї технологї, який є змінним для різних умов морфології відходів.

Досліджено потенційні переваги впровадження технологї̈ спільного спалення твердих побутових відходів у цементних печах. Застосовано методику оцінки викидів парникових газів для біогенних викидів при визначенні переваг та екологічного потенціалу при впровадженні технології. На прикладі української цементної промисловості визначено можливість: зменшення споживання антрацитового вугілля у виробництві клінкеру до 262 тис. m/piк; запобігання утворенню до 284 тис. m викидів $\mathrm{CO}_{2} е к в /$ рік від замімення вугілля. Для сектору поводження з відходами було визначено можливий потенціал від спільного спалення: утилізація побутових відходів до 1213 тис. тТПВ/рік; запобігання утворенню парникових газів до 111 тис.

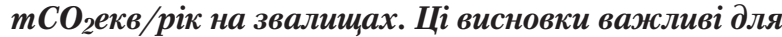
ряду краӥн, оскільки ключові бар'єри для здійснення спільного спалення відходів у цементних печах є спорідненими. Результати екологічного аналізу та запропоновані заходи щодо уникнення визначених ключових бар'єрів впровадження технологї можуть бути використані для умов багатьох крайн

Ключові слова: спільне спалення, ресурсозбереження, цементна промисловість, викиди парникових газів, ключові бар'єри
UDC 62-67

DOI: $10.15587 / 1729-4061.2019 .176942$

ENVIRONMENTAL

\title{
POTENTIAL ANALYSIS OF CO-PROCESSING WASTE IN CEMENT KILNS
}

A. Kleshchov $\mathrm{PhD}$, Lecturer

State Higher Education Institution

"Kyiv Electromechanical College"

Povitroflotskyi ave., 35, Kyiv, Ukraine, 03037

E-mail: anton.kleshchov@gmail.com

D. Hengevoss

Research Associate in Sustainable Resource Management*

O. Tere n t i e v

Doctor of Technical Sciences, Professor**

C. $\mathbf{H u g}$ i

Doctor of Technical Sciences, Professor, Lecturer in Sustainability and Development*

A. Safiants

$\mathrm{PhD}$

Department of Nuclear Power Stations and Engineering Thermal Physics***

Department of Heat-Physical Problems

of Heat Supply Systems

Institute of Engineering Thermophysics of National academy of sciences of Ukraine

Zhelyabova str., 2a, Kyiv, Ukraine, 03057

A. Vorfolomeiev $\mathrm{PhD}$, Senior Lecturer**

*School of Life Sciences FHNW Institute for Ecopreneurship

University of Applied Sciences and Arts Northwestern Switzerland

Hofackerstrasse, 30, Muttenz, Switzerland, 4132

**Department of Electromechanical Equipment

of Energy Intensive Industries Institute of Energy Saving and Energy Management*** $* \star *$ National Technical University of Ukraine "Igor

Sikorsky Kyiv Polytechnic Institute"

Peremohy ave., 37, Kyiv, Ukraine, 03056

Copyright (C 2019, A. Kleshchov, D. Hengevoss, O. Terentiev, C. Hugi, A. Safiants, A. Vorfolomeiev. This is an open access article under the CC BY license (http://creativecommons.org/licenses/by/4.0)

\section{Introduction}

Waste management has become a serious issue for today. Total waste generation, e. g. in Ukraine, is more than $69,000 \mathrm{kt} / \mathrm{a}$ (MSW (9\%) and industrial waste $(91 \%)$ ), mining and agricultural waste excluded [1]. Current waste management challenges in Ukraine and other countries can be described as follows [2]:

- accumulation of waste both from the industrial and domestic sectors in controlled and uncontrolled landfills 
having an adverse effect on the environment, human health and land space;

- improper treatment and disposal of hazardous waste from industries;

- disposal of MSW without separation of hazardous fractions (e. g. batteries, oil paints); waste).

- open burning of recyclable waste (e.g. paper, garden

According to the State Statistics Service [1], Ukraine generates more than 6 tons of unsorted waste per capita per year (total amount of municipal and industrial waste). It is higher than the average of the European Union, i. e. $4,931 \mathrm{~kg} / \mathrm{capita} /$ year in 2014 for EU-28 [3]. Currently, Ukrainian landfills are mostly outdated and overflowing, and therefore pose a quickly growing problem for the country. There are several projects aimed at biogas recovery in landfills in Ukraine (e.g. 26 biogas units in the beginning of 2018, according to the National Agency of Energy Efficiency and Energy Saving of Ukraine, while there are more than 300 landfills). However, it is not enough to improve the waste management situation. Because of an increasing level of collected MSW, the danger of soil and underground water contamination is quickly growing. MSW, even if it is only $9 \%$ of the total waste generation, is in the focus of the Ministry of Environment and Natural Resources of Ukraine and, therefore, of this study as well.

In Ukraine, waste separation and recycling are not done systematically yet. Waste infrastructure is largely outdated with some landfills built more than 40 years ago, overflowing with waste and being unsafe. Waste collection tariffs are too low to cover treatment costs, and the legal framework is complex [4]. This discouraged private investors from enterf ing the waste management market in the past.

For example, it is more expensive for waste collection companies to deliver waste to the only incineration plant in Ukraine ("Enerhiia"), located in Kyiv, than to dump the collected waste nearby, in uncontrolled landfills. Waste collection companies charge on average EUR 8.06 per ton for the collection of waste [5]. The gate fee of the incineration plant and legal landfills is about EUR 2.80 per ton. That means a waste collection company must spend about $30 \%$ of the income on incineration or landfilling. To avoid these treatment costs, the waste has often been dumped in illegal/ semi-legal landfills for about EUR 1.6 per ton. Due to weak enforcement of the environmental legislation, this practice, unfortunately, is still widely used today.

National and international cement companies operate modern cement kilns which could substitute a part of their fossil fuel and raw material with suitable waste streams to be co-processed. Using waste as a source for alternative energy and raw material could also reduce the dependency on them being imported.

Of course, prevention, reuse and material recycling are the most preferable options in an integrated waste management system and have higher priority than energy recovery from the point of view of society. Currently, a number of countries start to implement their strategies of sorting and separating waste, a precondition for recycling. However, co-processing non-recyclable waste is often a valid option to close loops towards a more circular economy. According to [6], as far as alternative materials are the case, utilizing waste-derived fuel and industrial by-products instead of conventional fuels and materials result in the significant emission mitigation. Industrial wastes which can be used as both fuel and raw material simultaneously mitigate emissions in cement plants and landfills.

\section{Literature review and problem statement}

According to the investigation [7], GHG mitigation is one of the most attractive benefits of co-processing of biomass. It has been established that co-processing of biomass has less $\mathrm{CO}_{2}$ emission compared with firing of coal proportionally to the amount of coal offset by biomass, considering biomass as a carbon-neutral source produced sustainably. It shows a possibility of co-processing of municipal solid waste as an alternative fuel for cement kilns.

The authors of [8] have analyzed the harmless disposal rate of sludge in China. It has been increased from $25 \%$ to more than $50 \%$ in the last 5 years due to the expansion of the sludge treatment scale. To avoid this, municipal solid sludge is widely used as an alternative fuel for cement kilns today. The study shows a gap of investigation of the carbon emissions of co-processing projects and the reduction benefits from energy and resource conservation.

As for the hazardous waste, in Gujarat (India) the utilization of it as an alternative fuel and input material in cement kilns increased by 35 times between 2009/2010, from 15,693 tons per annum, to 543,569 tons per annum in $2013 / 2014$ [9]. It has been proved that co-processing is thus a preferred solution in the waste management hierarchy for their current situation. It needs to be mentioned that India has a lot of similarities in the waste management system with Ukraine. The separation system and recycling are not strong, and the government has not enough investments for the higher priority waste management technologies implementation.

The same results have been investigated by the authors of [10]. The economy of Puerto Rico is shrinking in its presp ent recession. It is because the price of electricity has become a stumbling block to attract new investments, and because the supply of electrical energy seems to continue to be dependent on fossil fuels. The poor management and improper disposal of almost five million scrap tires (ST) generated annually on the Island have reached negative environmental, economic and social impacts. The authors demonstrated that the problem can be transformed into an opportunity for ST to become a renewable energy option. It has been shown that ST are an endemic sustainable energy supply, ideal for the cogeneration of electricity or for its inclusion in thermal processes, e. g. in co-processing.

The work [11] shows the results of life cycle assessment for co-processing of construction and demolition waste. As a result, the authors suggest that the purchase of recycled aggregates resulting from waste treatment is cost-effective only if the treatment plant is situated within a $30 \mathrm{~km}$ area. The study suggests that the price of recycled aggregates must be kept at least $20 \%$ lower than natural aggregates which at present disregards the aggregates produced from waste.

The authors of [12] investigated that waste co-incinerw ation has a non-significant role on $\mathrm{CO}_{2}$ emissions from the cement kiln and an important energy efficiency loss can be deduced from the industry performance data, which is rarely considered by life cycle analysis practitioners. If cement kilns are considered as another waste treatment option, the functional unit is usually $1 \mathrm{t}$ of waste to be treated. In this 
case, it has been observed that contradictory results may arise depending on the initial assumptions, generating high uncertainty in the results. Air emissions, as heavy metals, are quite relevant when assessing waste co-incineration, as the amount of pollutants in the input is increased. These results show a significant impact of waste morphology on the effectiveness of co-processing of waste in cement kilns.

In the work [13], the authors calculated the costs of setting up and running facilities of thermal co-processing of properly dried and processed MSW with raw materials (limestone, clay materials, silicates and iron oxides). This is needed for the production of clinker which has been proven to be an environmentally friendly process. This study shows the experience of $\mathrm{CO}_{2}$ reduction possibility using co-processing of municipal solid waste which could be shared with Ukrainian authorities as well.

The result for this paragraph is that co-processing of waste is widely used in different countries, but with different ecological impact. So, it is crucial to investigate the co-processing of waste impact, which is variable for different waste morphology conditions.

\section{The aim and objectives of the study}

The aim of the study is to estimate the environmental and resource saving potential of co-processing MSW fractions in cement kilns.

To achieve this aim, the following tasks have been formulated:

- to investigate legal, economic and institutional barriers that hinder its implementation in the context of improving the waste management system in general, and to provide opportunities for overcoming those barriers;

- to estimate potential benefits of implementation of this technology for the cement industry;

- to analyze possible benefits of implementation of co-processing investigated for the waste management sector.

\section{Co-processing of waste in cement kilns possibilities}

4. 1. Legal, economic and institutional barriers for the implementation of co-processing

According to the investigation [14], the main barriers for co-processing of waste implementation in different countries have been found.

In Belgium, policy makers should recognize the material recovery aspect of co-processing. Market distortions are due to support for power and heat production. To further increase co-processing a more level playing field between the regions on taxation is needed. Regionally different waste legislations lead to fiscal differences in waste pricing [14].

In Bulgaria, RDF quality and low landfill taxes remain amongst the other barriers preventing faster uptake of alternative fuel from waste [14]. Lack of solid waste infrastrucf ture and planning remain major issues slowing the diversion of waste from landfills and its use of alternative waste treatment methods.

The Czech Republic has strong bureaucratic barriers and the lack of suitable waste is the main limiting factor. As the availability of domestic high-quality wastes has peaked, the industry has to look for imports. Lengthy bureaucratic processes slow down the possibility of over-border waste trade [14].
France feels a lack of investment to upgrade processes, which hampers higher use of alternative fuels [14]. A gene eral inability in the cement industry to pursue technology upgrades is the main barrier to increased fuel substitution.

In Greece, there are strong bureaucratic barriers and the lack of suitable waste is the main limiting factor. Very limited availability of suitable waste, lengthy permitting process and lack of recognition in national waste management planning are limiting the co-processing potential in the country [14].

Low landfill taxes and lack of high-quality waste on the domestic market are the main limiting factors for Hungary [14]. As low landfill taxes disincentive production of high-quality pre-processed waste, the cement industry has to look for imports from abroad.

In Ireland, economic uncertainty, lengthy planning and licensing processes and the potential addition of incineration capacity form the main barriers for increasing co-processing. The economic recovery needs to continue to enable investments in co-processing. At two plants, the planning process has caused delays to further co-processing [14].

Mainly political issues are blocking the further uptake of waste in the Italian cement industry [14]. Opposition from regional political authorities supported by public and environmental groups has to be addressed to allow for increased waste uptake in the cement industry.

The cement sector is facing minimum barriers in Poland to further increase its co-processing rate. The waste management industry has to make sure that RDF produced is of high-quality as the cement industry is the main customer [14].

In Portugal, RDF quality and low landfill taxes remain amongst the last barriers preventing faster uptake of alternative fuel from waste. Poor quality of domestically produced RDF along with extremely low landfill taxes are the main barriers. However, the industry managed to gain public acceptance and faces no permitting issues [14].

In Sweden, strong competition for available waste is limiting further development of co-processing in the cement sector. Underdeveloped pre-processing industry, public opposition to incineration and co-processing along with low disposal fees and poor economic situation hamper increased waste uptake in the Spanish cement industry. A very strong competition for waste with one of the most developed incineration industries in the EU, which is the preferred option to co-processing, presents a major barrier to further fuel substitution. There is an opening however, if biomass resources can be mobilized [14].

Alternative fuel from waste availability, logistics and economics prevent faster growth of co-processing in the United Kingdom. Economics dictate the increased use of alternative fuel from waste; a lack of policy-based incentives, logistics challenges and availability of the volume of quality alternative fuel are the main barriers [14].

Germany has a well-developed waste to energy capacity and about $26 \%$ of the waste gets incinerated. However, ded spite a landfill ban, $22 \%$ of waste is still being disposed of. One of the reasons of this is a difference in GHG accounting between cement plants and incinerators [14].

Ukrainian legislation lacks specification of possible forms of public-private partnership to attract private investments in waste management. It does not define different models of cooperation of territorial communities with private partners (residents and/or non-residents) that have the necessary material and technical base and considerable 
experience in conducting entrepreneurial activity in the field of waste management. As most of the waste is created by the industrial sector, agricultural enterprises and municipalities, it is also an important challenge for the economic sector that should be more involved based on the polluter-pays principle. The formation of industrial waste management capacities should be one of the priorities of decentralization and local self-government reform, as well as attracting investments into waste management.

The key message of this paragraph is:

- The need for lower waste management technologies, which should improve the situation immediately is investigated. One of the possible technologies is co-processing of waste in cement kilns, which is widely used in the world. Moreover, according to [15], pre-processed MSW has high net calorific value (NCV) in gigajoules (GJ) per dry tonne (Table 1). Pre-processed MSW also has a much lower $\mathrm{CO}_{2}$ emissions factor compared to coal when burned in a cement kiln (Table 2).

Implementation of co-processing could help the countries to increase the recovery level in the waste management hierarchy and would be a step towards circular economy by transforming waste into revenue streams [16]. Waste could be used as an energy source (as an alternative fuel for cement rotary kilns) and as raw material (as part of clinker). However, co-processing should complement but not compete with other recycling approaches. The current waste management system in Ukraine is not yet able to cope with the rising generation of waste, which results in increasing landfill areas and environmental pollution. Co-processing could contribute to alter this trend together with the implementation of sorting and recycling infrastructure for the different waste streams.

The key message from this paragraph is: co-processing implementation could significantly contribute to reducing the amount of waste disposed in landfills, as discussed in the following section.

\section{2. Measures to mitigate barriers for co-processing} of waste

The key barriers the countries face on their way to implementing co-processing are comparable to the barriers also faced in China [17], plus the issue of increasing waste gene eration. China is now actively seeking to increase its waste recovery in cement kilns with producers such as Huaxin Wuxue and Sinoma's Liyang having taken up the challenge. They are assisted by the Chinese Research Academy of Environmental Sciences and by the Ministry of Environmental Protection [18]. This helps identify the following seven barn riers also encountered in Ukraine:

Costs: The costs of RDF generation usually exceed the existing landfill charges.

Potential solutions: The current landfill fees do not consider all external costs of future groundwater contamination or emissions of greenhouse gases, such as methane. Therefore, these external costs should be included in landfill fees or in financial incentive. Additional support programmes should be designed to ensure that the technology of co-processing waste is able to compete fairly with other waste management methods.

Financial support: Co-processing may not be financially viable if broader public waste management benefits are not taken into account, i. e. external costs.

Potential solutions: Municipalities and governments should develop programmes based on full costs and benefits accounting for local communities and the environment and need to play their part in the financing of waste management and co-processing.

Infrastructure: Currently, there is no infrastructure for pre-processing and transporting waste to cement plants.

Potential solutions: It is necessary to approve procedures for adequate separation of waste materials and to install specific equipment in order to produce high-quality RDF and treat the remaining waste adequately.

Lack of qualified workforce: Co-processing waste in cement plants requires highly skilled specialists and trained personnel to operate the equipment. This capacity is currently limited in most developing countries.

Potential solutions: The main cement producers in different countries are linked to such worldwide consortiums as CRH Group, IFCEM, BUZZI, Heidelberg, EuroCement [19]. Most of them have successful experience of implementing the technology of co-processing waste in cement kilns in other countries. Using this experience could help find effective options.

Permitting: Cement industry prefers uniform emission standards for co-processing. However, for co-processing certain hazardous types of waste individual permits are needed to ensure safety and compliance with the environmental standards.

Potential solutions: Providing standards for different types of alternative fuels could simplify the permitting for co-processing.

Public acceptance: A problem of waste incineration is the formation of emissions, especially dioxins, and therefore there is a legitimate concern of the population. Residents and local groups often associate co-processing with incineration and hinder the implementation with protests and legal actions.

Potential solutions: Basic knowledge about environmentally responsible co-processing and how it differs from incineration, as well as its potential benefits, needs to be shared with stakeholders at both national and local levels. Cement plants should publicly report emission monitoring data and information regarding the technology of co-processing waste to assure the communities that emissions of pollutants do not exceed permitted levels.

Regulations and standards: In some countries, there are no specific rules or standards for co-processing waste in cement kilns. Partial implementation of the waste management system in many developing countries is also one of the main barriers.

Potential solutions: Waste legislation should be harmonized with European legislation, and executive policy should be optimized (paragraph 4. 1).

The key message from this paragraph is:

- a number of countries face the following key barriers on the way to implementing the technology of co-processing waste in cement kilns: complicated process of permitting, myriad of regulations and standards, lack of financial support, no full cost accounting, public acceptance, lack of infrastructure and qualified workforce. These barriers could be addressed partly by the measures proposed in this paper.

4. 3. Estimation of potential benefits of implementation of co-processing of waste for the cement industry and for the waste management system

Cement manufacturing is an energy intensive process, and coal is commonly used as the main energy source. The estimation is provided for Ukrainian conditions, but it could be interesting for different countries and the methodology could be replicated. The cement industry consists currently 
of five national and international companies, which produce up to $9,000 \mathrm{kt}$ cement/a [20]. The main fraction of cement is clinker, which is produced in rotary kilns at temperatures of about $1,450{ }^{\circ} \mathrm{C}$. The Industrial Emission directive 2010/75/ EU defines the conditions for co-incineration (co-processing) waste in cement kilns. The key requirement is that the combustion gases are exposed to temperatures of at least $850{ }^{\circ} \mathrm{C}$ for at least two seconds. If hazardous waste with a content of more than $1 \%$ of halogenated organic substances, expressed as chlorine, is incinerated, the temperature must be raised to $1,100{ }^{\circ} \mathrm{C}$ for at least two seconds [21]. At this temperature, all organic compounds of the input materials are destroyed. As these conditions are well fulfilled by the technology of co-processing waste in cement kilns, it is a viable option for many high-calorific waste fractions as an alternative fuel and raw materials for clinker production.

Table 1 provides the results of $\mathrm{CO}_{2 \mathrm{eq}}$ emissions calculation for anthracite coal burning process and for mixed fuel burning process (i. e. 70/30 ratio of anthracite coal/RDF). Experimental data from Ukrainian cement plants, provided by the representative of the Ukrainian national association of cement producers "Ukrcement" were used. For calculations, it has been estimated that RDF contains plastic, textile, tires, construction and organic waste fractions (which is dried), according to the RDF production technology [22]. The second main estimation is specific calorific value, according to [23]. This is a bulk estif mation and, in reality, will depend on the MSW morphology of the individual landfill and the RDF production technology.

Table 1

Results of $\mathrm{CO}_{2 \text { eq }}$ specific emissions and specific RDF consumption for clinker production estimation for anthracite coal burning process and for mixed fuel burning process

\begin{tabular}{|c|c|}
\hline Parameter, unit & Value \\
\hline $\begin{array}{l}\text { Specific } \mathrm{CO}_{2 \mathrm{eq}} \text { emission for anthracite coal, } \\
\qquad \mathrm{kg}_{\mathrm{CO}_{2 \mathrm{eq}}} / \mathrm{kg}_{\text {fuel }}\end{array}$ & 3.37 [24] \\
\hline $\begin{array}{l}\text { Specific thermal heat energy requirements for clin- } \\
\text { ker production, } \mathrm{MJ} / \mathrm{t} \text { of clinker }\end{array}$ & $3.788[25]$ \\
\hline $\begin{array}{l}\text { Specific anthracite coal consumption for clinker } \\
\text { production, kg/t of clinker (experimental data from } \\
\text { Ukrainian cement plants) }\end{array}$ & 116.91 \\
\hline Calorific value of anthracite coal, $\mathrm{MJ} / \mathrm{kg}$ of coal & $32.4[26]$ \\
\hline $\begin{array}{l}\text { Specific } \mathrm{CO}_{2 \mathrm{eq}} \text { emission from anthracite coal in } \\
\text { clinker production, } \mathrm{kg}_{\mathrm{CO}_{2 \mathrm{eq}}} / \mathrm{t}_{\text {clinker }}\end{array}$ & 394 \\
\hline $\begin{array}{l}\text { Estimated substitution rate of anthracite coal with } \\
\text { RDF, \% of thermal energy }\end{array}$ & 30 \\
\hline Specific calorific value of RDF, MJ/kg & $24.1[23]$ \\
\hline $\begin{array}{l}\text { Calculated specific RDF consumption in clinker pro- } \\
\text { duction, } \mathrm{kg}_{\mathrm{RDF}} / \mathrm{t}_{\text {clinker }} \text { (by using data from this table) }\end{array}$ & 47.15 \\
\hline $\begin{array}{l}\text { Specific fossil } \mathrm{CO}_{2 \mathrm{eq}} \text { emission from RDF, } \\
\qquad \mathrm{kg}_{\mathrm{CO}_{2 \mathrm{eq}}} / \mathrm{kg}_{\mathrm{RDF}}\end{array}$ & $1.7[23]$ \\
\hline $\begin{array}{l}\text { Calculated specific emission for co-processing, } \\
\mathrm{kg}_{\mathrm{CO}_{2 \mathrm{eq}}} / \mathrm{t}_{\text {clinker }} \text { (by using data from this table) }\end{array}$ & 356 \\
\hline
\end{tabular}

The specific $\mathrm{CO}_{2 \mathrm{eq}}$ emissions could be reduced by about $15 \%$ through co-processing at an energy substitution rate of $30 \%$, Table 1 .

In Table 2, ecological and resource potential, estimated for the Ukrainian cement industry in case of co-processing implementation is shown. The following was assumed for the calculation:
- Traditional fuel used - anthracite coal;

- Alternative fuel - mixed with traditional with the ratio of $70 \%$ anthracite coal per $30 \%$ RDF from MSW.

Co-processing with the above alternative fuel mix is implemented at all Ukrainian cement enterprises.

Table 2

Calculation of the yearly $\mathrm{CO}_{2 \mathrm{eq}}$ and anthracite coal reduction potential by co-processing RDF in the Ukrainian cement industry

\begin{tabular}{|c|c|}
\hline Parameter, unit & Value \\
\hline Average annual cement production, kt/a & $8,798[25]$ \\
\hline $\begin{array}{l}\text { Share of clinker in cement, \% (experimental data } \\
\text { from Ukrainian cement plants) }\end{array}$ & 85 \\
\hline $\begin{array}{l}\text { Calculated average annual clinker production, kt/a } \\
\text { (by using data from this table) }\end{array}$ & 7,478 \\
\hline $\begin{array}{c}\text { Calculated total annual anthracite coal consumption } \\
\text { for clinker production, GJ/a } \\
\text { (by using data from Table } 1,2 \text { ) }\end{array}$ & $28,327.800$ \\
\hline Calorific value of anthracite coal, $\mathrm{MJ} / \mathrm{kg}$ & $32.4[26]$ \\
\hline $\begin{array}{c}\text { Calculated total annual anthracite coal consumption } \\
\text { for clinker production, kt/a } \\
\text { (by using data from Table } 1,2 \text { ) }\end{array}$ & 874.31 \\
\hline $\begin{array}{c}\text { Specific anthracite coal consumption for clinker } \\
\text { production, kg/t (experimental data from Ukrainian } \\
\text { cement plants) }\end{array}$ & 116.91 \\
\hline $\begin{array}{c}\text { Calculated potential reduction of anthracite coal } \\
\text { consumption for clinker production, kt/a } \\
\text { (by using data from this table) }\end{array}$ & 262 \\
\hline $\begin{array}{l}\text { Calculated average annual } \mathrm{CO}_{2 \mathrm{eq}} \text { emission, } \\
\mathrm{kt}_{\mathrm{CO}_{2 \mathrm{eq}}} / \mathrm{a} \text { (by using data from this table) }\end{array}$ & 2,946 \\
\hline $\begin{array}{l}\text { Calculated potential reduction for } \mathrm{CO}_{2 \mathrm{eq}} \text { emissions } \\
\text { from substitution of anthracite coal, } \mathrm{kt}_{\mathrm{CO}_{2 \mathrm{eq}}} / \mathrm{a} \\
\text { (by using data from this table) }\end{array}$ & 284 \\
\hline
\end{tabular}

By using the methodology from RTI [27], for landfills without gas collection systems, $\mathrm{CO}_{2}$ emissions can be calculated from the $\mathrm{CH}_{4}$ generation as follows:

$B=A \cdot(((1-F) / F)+O X) \cdot 44 / 16$,

where $B$ is $\mathrm{CO}_{2}$ emissions, t/a; $A$ is $\mathrm{CH}_{4}$ generation, $\mathrm{t}_{\mathrm{CH}} / \mathrm{a}$; $F=0.5$ is fraction by volume of $\mathrm{CH}_{4}$ in landfill gas, $-; O X=0.1$ is soil oxidation fraction, -; 44 is molecular weight of $\mathrm{CO}_{2}, \mathrm{~kg} / \mathrm{kg} \cdot \mathrm{mol} ; 16$ is molecular weight of $\mathrm{CH}_{4}, \mathrm{~kg} / \mathrm{kg} \cdot \mathrm{mol}$.

Model for $\mathrm{CH}_{4}$ generation is as follows:

$$
A=\left[\sum_{x=S}^{T-1}\left\{W_{x} \cdot L_{x} \cdot\left(e^{-k \cdot(T-x-1)}-e^{-k \cdot(T-x)}\right)\right\}\right],
$$

where $A$ is $\mathrm{CH}_{4}$ generation, $\mathrm{t} / \mathrm{a} ; x$ is year in which waste was disposed, $-; S$ is start year of inventory calculation, $-; T$ is inventory year for which emissions are calculated, $-; W_{x}$ is the quantity of waste disposed at the solid waste disposal site, $\mathrm{t}$; $L^{\prime}=L_{0} \cdot 16 / 0.02367 \cdot 10^{-6}$ is $\mathrm{CH}_{4}$ generation potential, $\mathrm{t}_{\mathrm{CH}_{4}} / \mathrm{t}_{\text {waste }} ; L_{0}$ is $\mathrm{CH}_{4}$ generation potential, $\mathrm{m}_{\mathrm{CH}_{4}}^{3} / \mathrm{t}_{\text {waste }} ; k$ is decay rate constant, $\mathrm{a}^{-1}$.

$L_{0}$ can be calculated from the degradable organic carbon value:

$$
L_{0}=493 \cdot D O C,
$$

where $L_{0}$ is $\mathrm{CH}_{4}$ generation potential, $\mathrm{m}_{\mathrm{CH}_{4}}^{3} / \mathrm{t}_{\text {waste }} ; D O C$ is degradable organic carbon, $\mathrm{t}_{\mathrm{C}} / \mathrm{t}_{\text {waste }}$. 
Basic data from [28, 29], the specific amount of GHG landfill gas emissions per ton of MSW for Ukraine has been estimated by considering the type of waste and its share in MSW by using (1), (2) and (3). The specific amounts add up to about $90 \mathrm{~kg}_{\mathrm{CO}_{\mathrm{eq}}} / \mathrm{t}_{\mathrm{MSW}}$.

To estimate the total amount of MSW, which is required for producing the needed amount of RDF for co-processing in Ukraine, an analogy based on the ratios of four countries for RDF production from [30] has been used. It shows that $100 \mathrm{~kg}$ of RDF production requires on average $344 \mathrm{~kg}$ of MSW. The authors of the investigation [31] have estimated close results that $312 \mathrm{~kg} / \mathrm{h}$ of MSW are required to produce $107 \mathrm{~kg} / \mathrm{h}$ of RDF, assuming that $50 \%$ of total MSW are recyclables (ceramics, metals, plastics, glasses, etc.), water flow in the separated MSW total flow is about $43 \mathrm{~kg} / \mathrm{h}$; act cording to real (actual) operation of MSW handling, there were considerable material losses in the milling $(3 \%)$ and briquetting ( $2 \%$ ) operations [31].

Table 3 shows a potential of about 1,213 kt/a of MSW which could be treated for RDF production. The GHG landfill gas mitigation potential could reach up to $111 \mathrm{kt}_{\mathrm{CO}_{2 \mathrm{eq}}} / \mathrm{a}$.

Table 3

Potential MSW treatment for RDF and GHG reduction from landfills

\begin{tabular}{|c|c|}
\hline Parameter & Value \\
\hline $\begin{array}{l}\text { Specific RDF consumption for clinker production, } \mathrm{kg} / \mathrm{t} \\
\text { (data from Table 1) }\end{array}$ & 47.15 \\
\hline Average annual clinker production, kt/a (data from Table 2) & 7,478 \\
\hline $\begin{array}{l}\text { Calculated average annual RDF consumption, kt/a } \\
\text { (by using data from this table) }\end{array}$ & 350 \\
\hline $\begin{array}{c}\text { Calculated MSW to RDF ratio, } \mathrm{t}_{\mathrm{MSW}} / \mathrm{t}_{\mathrm{RDF}} \\
\text { (by using data from [30]) }\end{array}$ & 3.44 \\
\hline $\begin{array}{c}\text { Calculated potential MSW treatment for RDF, kt/a } \\
\text { (by using data from this table) }\end{array}$ & 1.213 \\
\hline $\begin{array}{l}\text { Calculated potential of reducing GHG emissions from } \\
\text { landfills, } \mathrm{ktCO}_{2 \mathrm{eq}} / \mathrm{a} \text { (by using data from this table) }\end{array}$ & 111 \\
\hline
\end{tabular}

This estimated theoretical potential of co-processing RDF in the Ukrainian cement industry to substitute up to $262 \mathrm{kt} / \mathrm{a}$ of anthracite coal could hardly be completely utilized. Nevertheless, a reduction of up to $1,213 \mathrm{kt}_{\mathrm{MSW}} / \mathrm{a}$ disposed in landfills seems as an interesting treatment path until better options according to the waste hierarchy, as presented in Fig. 4, are made available. According to the IFC [28], in 2013 the recovery rate in Ukraine was only $3 \%$ to $8 \%$ of generated MSW. By 2025, the Ukrainian recovery rate must increase up to $41 \%$ [28]. The potential of using MSW for RDF production is more than $19 \%$ of the total annual MSW generation in Ukraine (6,346.50 $\left.\mathrm{kt}_{\mathrm{MSW}} / \mathrm{a}\right)$ [1].

It needs to be mentioned that decreasing of $\mathrm{CO}_{2}$ emissions is possible, only if pre-treatment of waste streams has exact quality. If calorific value, humidity, morphology or fracture size of prepared and treated waste has low quality, emissions from its co-processing will be increased.

\section{Results of the environmental potential analysis of co-processing of waste}

The technology of co-processing with RDF rate of $30 \%$ could substitute up to $262 \mathrm{kt} / \mathrm{a}$ of anthracite coal consumption in the clinker production in Ukraine.
MSW disposal amount could be reduced to 1,213 $\mathrm{kt}_{\mathrm{MSW}} / \mathrm{a}$ which is about $20 \%$ of total annual MSW generation in Ukraine.

Anthracite coal consumption for clinker production could be reduced up to $30 \%$.

Annual $\mathrm{CO}_{2 \mathrm{eq}}$ emissions from MSW at landfills reduction potential is up to $10 \%$.

Total $\mathrm{CO}_{2 \mathrm{eq}}$ reduction potential is up to $395 \mathrm{kt}_{\mathrm{CO}_{2 \mathrm{eq}}} / \mathrm{a}$, which is up to $0.3 \%$ of Ukrainian total annual $\mathrm{CO}_{2 \mathrm{eq}}$ generation.

The scientific novelty of this study is as follows. The method of estimation of greenhouse gas emissions for biogenic emissions from separate categories of sources determined the specific amount of greenhouse gas emissions from landfills for the existing situation and for the conditions of introduction of co-incineration technology in cement kilns. The type of waste and its share in the landfill were considered. Considering the morphology of the waste, the environmental potential was analyzed not only for the waste sector but also for clinker production, which allows to achieve the task - to estimate the environmental potential for co-processing of waste implementation. This is one of the key barriers for the list of countries for co-processing of waste implementation (e. g. for Germany or for Ukraine). So, the proposed methodt ology of environmental potential could be used for different countries to show benefits of co-processing of waste.

\section{Discussion of possibilities of co-processing waste} in cement kilns

The technology of co-processing waste in cement kilns is a viable option and could contribute substantially to achieve this goal. The total $\mathrm{CO}_{2 \mathrm{eq}}$ reducing potential has been estimated to be up to $400 \mathrm{kt}_{\mathrm{CO}_{2 \mathrm{eq}}} / \mathrm{a}$ (which is up to $0.3 \%$ of Ukrainian total annual $\mathrm{CO}_{2 \text { eq }}$ generation), which includes up to $111 \mathrm{kt}_{\mathrm{CO}_{2 \mathrm{eq}}} / \mathrm{a}$ from landfills and up to $284 \mathrm{kt}_{\mathrm{CO}_{2 \mathrm{eq}}} / \mathrm{a}$ from substitution of fossil fuel in clinker production.

Fig. 1 shows the expected benefits for the environment and resource consumption for a full co-processing implementation in Ukraine.

These results are important for the number of countries, because the key barriers for implementation of co-processing are comparable, as it was shown in the literature review before. The provided environmental analysis and proposed measures to mitigate the barriers for co-processing of waste for Ukrainian conditions could be multiplicated in different countries.

Some stakeholders are concerned that some constituents contained within some wastes that are recovered for use as either raw materials or fuel could influence the concrete or be released from the cement product or concrete. This concern is heightened as concrete is a major component of residential construction and is often used in pipes. The topic has been the subject of numerous research studies over the last 20 years and more. Aggrest sive testing carried out by NSF/ANSI Standard 61 [32] (a third party certification process for drinking water pipes in the United States) has shown that metals in the cement become bound in the concrete calcium silicate structure and in this form do not leach from the product. Similar results have been reported in many other reports by the Association Technique de l'Industrie des Liants Hydrauliques [33], Construction Technology Laboratoe ries [34], Forschungsinstitut der Zementindustrie [35], 
Cembureau [36], the European Committee for Standarde ization [37], etc. There is substantial evidence that cee ment manufactured from the types of waste recommended in these guidelines does not change the performance or characteristics of the cement or concrete; high levels of some minor components can affect cement performance, and the manufacturer needs to take care that specific thresholds are not exceeded [38].

The proposed methodology shows the basis numbers for argumentation of co-processing of waste in cement kilns benefits, which could be found in several specific multipliable steps (it is general for different countries, just the morphology of waste in the region needs to be checked). Such estimation is not provided in $[39,40]$, which are the basis for the certification of co-processing plants.

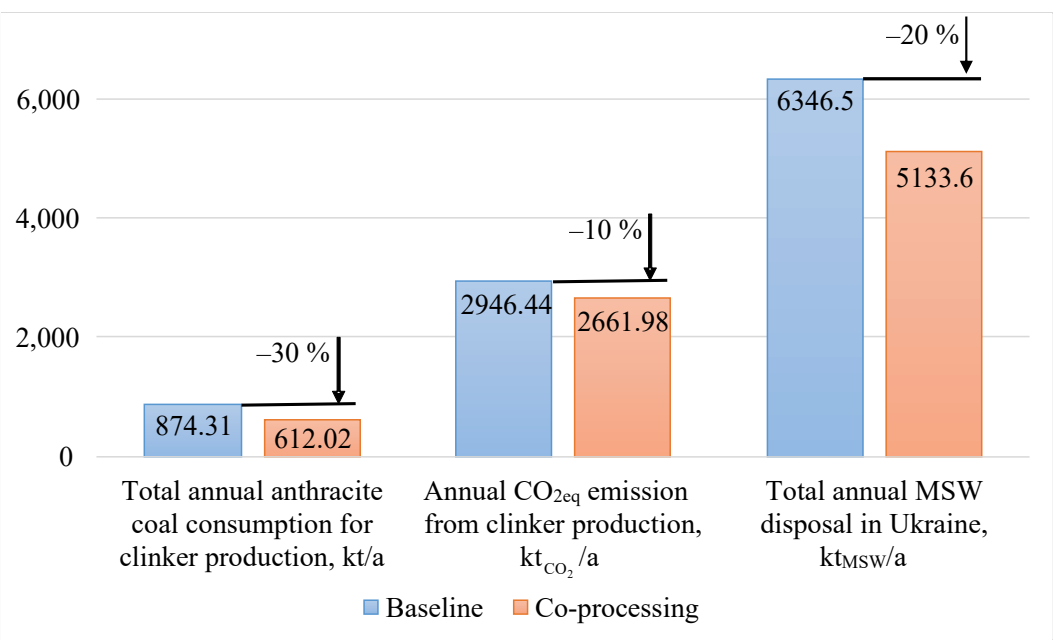

Fig. 1. Estimated benefits for the environment and resource consumption of a comprehensive co-processing implementation in Ukraine

The investigation proposes a short basis step-by-step calculation of environmental potential estimation, which could be used for the preparation of project documents or the argumentation for governments.

The threats of the investigations could be the next:

- not proper estimation of the morphology of waste in the region, which is the basis data for all environmental potential calculations. For some regions, the waste morphology could be not accepted, or it will less high calorific fractures for co-processing in cement kilns;
- not considered season variation of waste (e. g. in touristic regions), which could influence the result of the calculations.

\section{Conclusions}

1. The list of countries are faced with the following key barriers on the way to implementing the technology of co-processing waste in cement kilns: lack of methodologies for investigating the benefits of co-processing of waste implementation, complicated process of permitting, myriad of regulations and standards, lack of financial support, no full cost accounting, public acceptance, lack of infrastructure and qualified workforce. A list of potential solutions and a methodology for the environmental potential of co-processing of waste investigation were proposed.

2. The potential benefits of implementan tion of the co-processing of waste in cement kilns technology for the Ukrainian cement industry using experimental data on specific fuel consumption and clinker share value:

- decreasing anthracite coal consumption in clinker production by $262 \mathrm{kt} / \mathrm{a}$;

- preventing up to $284 \mathrm{kt}_{\mathrm{CO}_{2 \mathrm{ea}}}$ emissions per year from substitution of coal in clinker production.

3. For the Ukrainian waste managea ment sector, possible benefits of implementation of co-processing were investigated:

- energy recovery up to $1,213 \mathrm{kt}_{\mathrm{MSW}} / \mathrm{a}$ (which is $19 \%$ of total amount of municipal solid waste generated annually in Ukraine);

- prevention of up to $111 \mathrm{kt}_{\mathrm{CO}_{2 \mathrm{eq}}} / \mathrm{a}$ of GHG emissions from landfills.

\section{Acknowledgments}

The authors would like to thank the Deutsche Gesellschaft fur Internationale Zusammenarbeit (GIZ) $\mathrm{GmbH}$ and Geocycle (LafargeHolcim Ltd) for their support and Ukrainian national association of cement producers "Ukrcement" for discussions and provided experimental data during the preparation of this research.

\section{References}

1. Wastes generation by type of economic activity in 2005-2016. Available at: https://ukrstat.org/en/operativ/operativ2016/ns/ ns_e/utv_za_ek_d_e2016.html

2. Ukrainian National Waste Management Strategy Until 2030 Approved. Available at: http://dlf.ua/en/ukrainian-national-waste-management-strategy-until-2030-approved

3. Waste generation by economic activities and households. Available at: https://ec.europa.eu/eurostat/statistics-explained/ index.php?title=File:Waste_generation_by_economic_activities_and_households,_2014-1.png

4. Demus, V., Zhechkov, R. (2014). Background Paper on Financing Waste Management in Ukraine. Regional environmental center, 8-15.

5. Doslidzhennia okremykh pytan utylizatsiyi vidkhodiv na terytoriyi mista Kyieva. URL: http://publicaudit.com.ua/reports-on-audit/ doslidgennya-okremyh-pytan-ytilizacii-vidhodiv-na-terytorii-mista-kieva

6. Benhelal, E., Zahedi, G., Shamsaei, E., Bahadori, A. (2013). Global strategies and potentials to curb CO2 emissions in cement industry. Journal of Cleaner Production, 51, 142-161. doi: https://doi.org/10.1016/j.jclepro.2012.10.049 
7. Tchapda, A., Pisupati, S. (2014). A Review of Thermal Co-Conversion of Coal and Biomass/Waste. Energies, 7 (3), $1098-1148$. doi: https://doi.org/10.3390/en7031098

8. Xu, J., Ping, L., Cao, H., Liu, W., Gu, Y., Lin, X., Huang, J. (2019). Application Status of Co-Processing Municipal Sewage Sludge in Cement Kilns in China. Sustainability, 11 (12), 3315. doi: https://doi.org/10.3390/su11123315

9. Karthikeyan, L., Suresh, V., Krishnan, V., Tudor, T., Varshini, V. (2018). The Management of Hazardous Solid Waste in India: An Overview. Environments, 5 (9), 103. doi: https://doi.org/10.3390/environments5090103

10. Laboy-Nieves, E. (2014). Energy Recovery from Scrap Tires: A Sustainable Option for Small Islands like Puerto Rico. Sustainability, 6 (5), 3105-3121. doi: https://doi.org/10.3390/su6053105

11. Mihai, F.-C. (2019). Construction and Demolition Waste in Romania: The Route from Illegal Dumping to Building Materials. Sustainability, 11 (11), 3179. doi: https://doi.org/10.3390/su11113179

12. Galvez-Martos, J.-L., Schoenberger, H. (2014). An analysis of the use of life cycle assessment for waste co-incineration in cement kilns. Resources, Conservation and Recycling, 86, 118-131. doi: https://doi.org/10.1016/j.resconrec.2014.02.009

13. Sikalidis, A., Emmanouil, C. (2019). Description and Economic Evaluation of a "Zero-Waste Mortar-Producing Process" for Municipal Solid Waste Management in Greece. Journal of Open Innovation: Technology, Market, and Complexity, 5 (3), 46. doi: https://doi.org/10.3390/joitmc5030046

14. De Beer, J., Cihlar, J., Hensing, I. (2017). Status and prospects of co-processing of waste in EU cement plants. ECOFYS. Available at: https://cembureau.eu/media/1695/x12950-ecofys-co-processing-waste-cement-kilns-case-studies-2017-05.pdf

15. Hasanbeigi, A., Price, L., Lu, H., Williams, C. (2012). International best practices for pre-processing and co-processing municipal solid waste and sewage sludge in the cement industry. In European council for an energy efficient economy. Industrial Summer Study proceedings. ECEEE. Available at: https://www.eceee.org/library/conference_proceedings/eceee_Industrial_Summer_Study/2012/2-sustainable-production-design-and-supply-chain-initiatives/international-best-practices-for-pre-processing-and-co-processing-municipal-solid-waste-and-sewage-sludge-in-the-cement-industry/

16. Romero-Hernández, O., Romero, S. (2018). Maximizing the value of waste: From waste management to the circular economy. Thunderbird International Business Review, 60 (5), 757-764. doi: https://doi.org/10.1002/tie.21968

17. Hasanbeigi, A., Lu, H., Williams, C., Price, L. (2012). International Best Practices for Pre-Processing and Co-Processing Municipal Solid Waste and Sewage Sludge in the Cement Industry. Ernest Orlando Lawrence Berkeley National Laboratory. doi: https://doi.org/10.2172/1213537

18. MSW co-processing in China. Available at: https://www.cemnet.com/Articles/story/153118/msw-co-processing-in-china.html

19. UkrCement. Association of Cement Producers of Ukraine. Available at: http://ukrcement.com.ua/en/

20. Ukraine Cement Production. Available at: https://tradingeconomics.com/ukraine/cement-production

21. Waste incineration. Available at: https://eur-lex.europa.eu/legal-content/EN/TXT/?uri=LEGISSUM\%3Al28072

22. Weerasak, T., Sanongraj, S. (2015). Potential of Producing Refuse Derived Fuel (RDF) from Municipal Solid Waste at Rajamangala University of Technology Isan Surin Campus. Applied Environmental Research, 37 (2), 85-91.

23. Schwarzböck, T., Aschenbrenner, P., Spacek, S., Szidat, S., Rechberger, H., Fellner, J. (2018). An alternative method to determine the share of fossil carbon in solid refuse-derived fuels - Validation and comparison with three standardized methods. Fuel, 220, 916-930. doi: https://doi.org/10.1016/j.fuel.2017.12.076

24. Combustion of Fuels - Carbon Dioxide Emission. Available at: https://www.engineeringtoolbox.com/co2-emission-fuels-d_1085.html

25. Sarc, R., Pomberger, R., Lorber, K. (2017). Innovative Technical Solutions for Reduction of Waste Fuel Specific Emissions in Cement Plant. Neuruppin, 475-497.

26. Types (Ranks) of Coal. Available at: https://www.stovesonline.co.uk/coal-types.html

27. Greenhouse Gas Emissions Estimation Methodologies for Biogenic Emissions from Selected Source Categories: Solid Waste Disposal Wastewater Treatment Ethanol Fermentation. Available at: https://www3.epa.gov/ttnchie1/efpac/ghg/GHG_Biogenic_Report_draft_Dec1410.pdf

28. Municipal Solid Waste in Ukraine: Development Potential. Scenarios for developing the municipal solid waste management sector. Available at: https://www.ifc.org/wps/wcm/connect/24f11a48-d7a0-4970-9bd1-37ff9244f60e/21.+Municipal+Solid+Waste+in+Ukraine+DEVELOPMENT+POTENTIAL+Scenarios+for+developing +the+municipal+solid+waste+management+sector+.pdf?MOD=AJPERES\&CVID=lNpD-tO

29. Jeon, E.-J., Bae, S.-J., Lee, D.-H., Seo, D.-C., Chun, S.-K., Lee, N. H., Kim, J. Y. (2007). Methane Generation Potential and Biodegradability of MSW Components. Proceedings Sardinia 2007, Eleventh International Waste Management and Landfill Symposium S. Margherita di Pula. Cagliari. Available at: http://www.web-resol.org/textos/195.pdf

30. Gendebien, A., Leavens, A., Blackmore, K., Godley, A., Lewin, K., Whiting, K. J. et. al. (2003). Refuse Derived Fuel, Current Practice and Perspectives. CISA, Environmental Sanitary Engineering Centre, Report CO 5087-4. In: European Commission - Directorate General Environment. Swindon, 33-38. 
31. N sner, A. M. L., Lora, E. E. S., Palacio, J. C. E., Rocha, M. H., Restrepo, J. C., Venturini, O. J., Ratner, A. (2017). Refuse Derived Fuel (RDF) production and gasification in a pilot plant integrated with an Otto cycle ICE through Aspen plus ${ }^{\mathrm{TM}}$ modelling: Thermodynamic and economic viability. Waste Management, 69, 187-201. doi: https://doi.org/10.1016/j.wasman.2017.08.006

32. Colucci, M., Epstein, P., Bartley, B. (1993). A Comparison of Metal and Organic Concentrations in Cement and Clinker Made with Fossil Fuels to Cement and Clinker Made with Waste Derived Fuels. MI: NSF International, 5-18.

33. Germaneau, B., Bollotte, B., Defossé, C. (1993). Leaching of Heavy Metals by Mortar Bars in Contact with Drinking and Deionized Water. In Portland Cement Association Symposium - Concrete in the global environment, 1-4.

34. Kanare, H., West, P. (1993). Leachability of Selected Chemical Elements from Concrete. In Portland Cement Association Symposium - Concrete in the global environment, 6-8).

35. Thielen, G., Spanka, G., Rechenberg, W. (1993). Leaching characteristics of cement bound materials containing organic substances and inorganic trace element. In Portland Cement Association Symposium - Concrete in the global environment.

36. Cembureau (2005). Trace Elements Leaching from Concrete and the Use of Alternative Resources.

37. A study of the characteristic leaching behaviour of hardened concrete for use in the natural environment (1999). European Committee for Standardization.

38. Guidelines for Co-Processing Fuels and Raw Materials in Cement Manufacturing (2014). Cement Sustainability Initiative (CSI). Available at: https://docs.wbcsd.org/2015/10/CSI_Co-Processing_Fuels_and_Raw_Materials.pdf

39. ISCC 205 Greenhouse Gas Emissions. Available at: https://www.iscc-system.org/wp-content/uploads/2017/02/ISCC_205_ GHG_Emissions_3.0.pdf

40. ISCC 203-01 Guidance for the Certification of Co-Processing. Available at: https://www.iscc-system.org/wp-content/uploads/ 2017/02/ISCC-Guidance-Document-203-01_Co-processing-requirements.pdf 